\title{
SALIVA ACIDITY LEVEL TOWARD APPLICATION CASEIN PHOSPHOPEPTIDE - AMORPHOUS CALCIUM PHOSPHATE FOR CHILDREN AGED 8-9 YEARS
}

Anie Apriani*, Henry Yonatan Mandalas**, William Khoe ${ }^{* * *}$

* Staff Pengajar Ilmu Kedokteran Gigi Anak Fakutas Kedokteran Gigi Universitas Kristen Maranatha

** Staff Pengajar Ilmu Periodontology Fakutas Kedokteran Gigi Universitas Kristen Maranatha

*** Mahasiswa Fakutas Kedokteran Gigi Universitas Kristen Maranatha

Correspondence: henry.yonatan@dent.maranatha.edu

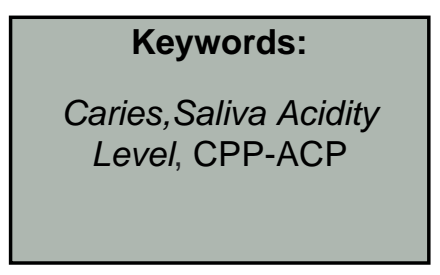

\begin{abstract}
Background: Dental caries is a disease of dental hard tissue that is often found in children. The etiology of dental caries is very diverse and multifactorial, one of which is the decreased acidity of saliva. There are many efforts and ways to reduce the incidence of dental caries, one of which is the application of topical flour to the teeth. Casein phosphopeptide-amorphous calcium phosphate (CPP-ACP) as a type of topical flour used has been shown to reduce demineralization and increase tooth remineralization. This study aimed to determine the acidity level of saliva before and after application of CPP-ACP in children aged 8-9 years.
\end{abstract}

Methods: Measurement of salivary acidity was measured using a digital $\mathrm{pH}$ meter in the study sample of 42 children consisting of 23 boys and 19 girls. Subjects were applied CPP-ACP for 1 month with the routine application once a week, then re-examined the salivary acidity level after 1 month.

Result : The average result of salivary acidity before CPP-ACP application was 6.928 and after CPP-ACP application was 7.0611. The T-test resulted in a very significant difference in the level of salivary acidity before and after the application of CPP-ACP.

Conclusion : is that Tthere are differences in the level of salivary acidity in children aged 8-9 years before and after topical application of CPP-ACP flour.

\section{PENDAHULUAN}

IImu pengetahuan kedokteran gigi berkembang pesat, sejak banyaknya faktor mengenai penyebab karies gigi serta perkembangan dari karies tersebut. Pada saat ini, banyak ahli berpendapat bahwa karies gigi merupakan suatu penyakit yang dapat mempengaruhi ke gigi lainnya akibat dari banyaknya faktor penyebab karies tersebut. ${ }^{1}$ Faktor-faktor kebiasaan diet, kualitas, dan kuantitas plak gigi, kualitas dan kuantitas saliva, usia dan imunitas tubuh, kebersihan mulut, mikroflora oral, kondisi gigi dan faktor-faktor genetik merupakan penyebab yang potensial pada karies gigi. ${ }^{1,2}$

Selain bakteri Streptococcus mutans sebagai bakteri penyebab karies, saliva merupakan salah satu faktor yang mempengaruhi kerentanan jaringan terhadap intesitensitas proses karies. Lingkungan gigi juga dapat diasamkan oleh tingkat aliran saliva, viskositas dan $\mathrm{pH}$ saliva. ${ }^{3}$ Saliva memiliki peran utama dalam proses karies sebagai lingkungan aktivitas bakteri. ${ }^{4}$ 
Peranan saliva sangat penting dimulai dengan pembersihan permukaan gigi secara mekanis dan melarutkan makanan serta fungsi lainnya sebagai lubrikasi, pelindung mukosa, menjaga buffer saliva, dan lain sebagainya. ${ }^{5}$ Nilai tingkat keasaman saliva normal berkisar 5,75 dan 6,5; nilai yang rendah menunjukkan keasaman lingkungan rongga mulut yang pada pasien sehat dapat berasal dari kebersihan yang kurang pada rongga mulut, banyaknya lesi karies, akumulasi kalkulus gigi, atau diet yang tidak tepat. ${ }^{6}$ Pengujian tingkat keasaman saliva memungkinkan untuk memprediksi aktivitas bakteri penginduksi karies. ${ }^{7}$ Saliva juga merupakan sumber informasi mengenai kondisi kesehatan rongga mulut, dan juga mudah untuk mendapatkan bahan penelitian. Pengujian tingkat keasaman saliva bersifat noninvasif dan tidak membutuhkan peralatan medis khusus. ${ }^{8}$

Aplikasi fluor topikal seperti varnish yang digunakan untuk mencegah karies gigi telah dilaporkan oleh banyak peneliti dan telah dikonfirmasi sesuai tinjauan sistematis dan meta analisis. Beberapa penelitian telah menunjukkan pengaruh topikal fluor dapat menurunkan risiko terhadap karies gigi. Topikal fluor Casein Phosphopeptide - Amorf Calsium Phospat (CPP$\mathrm{ACP}$ ) yang mengandung fluor dapat mengurangi jumlah S. mutans pada saliva anak, sehingga dapat mengurangi faktor risiko terjadinya karies gigi. ${ }^{9}$

\section{METODE PENELITIAN}

Sampel saliva diambil dari anak usia 8-9 tahun di Sekolah Dasar Sukasari dan Cibogo Kecamatan Sukajadi Kota Bandung. Jumlah sampel berjumlah 42 orang anak yang telah mengisi informed consent dan telah disetujui komite etik Fakultas Kedokteran Gigi, Universitas Trisakti (No 228/S2-Sp/KEPK/FKG/11/2018).

Alat pengukur $\mathrm{pH}$ saliva menggunakan $\mathrm{pH}$ meter digital ( Orion Star A221/ Stara 2215 Thermo Scientific). Bahan yang digunakan dalam penelitian CPP-ACP yang merupakan fluor topikal mirip seperti varnish dengan kandungan CPP-ACP. Bentuk sediaan berupa varnish fluor dengan CPP. ACP (MI dari GC corporation Japan) (Natrium fluoride $5 \% \mathrm{w} / \mathrm{w}$ dan CPP-ACP $2 \% \mathrm{w} / \mathrm{w}$ ).

Pengambilan sampel saliva dilakukan sebelum aplikasi CPP-ACP. Subjek penelitian melakukan spiting ke tabung $50 \mathrm{ml}$,lalu diukur $\mathrm{pH}$ saliva dan dicatat. Setelah itu subjek penelitian melakukan sikat gigi kemudian diaplikasikan CPPACP ke seluruh permukaan gigi menggunakan aplikator. Perlakuan dilakukan satu minggu sekali dan diulang terus selama satu bulan.

Hasil penelitian diuji menggunakan analisa statistik, yang dilakukan dengan uji $\mathrm{T}$ dengan menggunakan software SPSS.

\section{HASIL PENELITIAN}

Hasil penelitian terhadap pengukuran tingkat keasaman saliva pada anak usia 8-9 tahun sebanyak 44 anak 2 anak tidak mengikuti penelitian sampai akhir sehingga jumlah keseluruhan yang mengikuti penelitian sebanyak 42 orang anak yang terdiri dari anak laki laki 23 orang (54,8\%) dan perempuan 19 orang $(45,2 \%)$.

Tabel 1. Distribusi Sampel Penelitian

\begin{tabular}{llll}
\hline Sekolah Dasar & $\mathbf{L}(\%)$ & $\mathbf{P}(\%)$ & Jumlah (\%) \\
\hline Sukasari & $14(53,8)$ & $12(46,2)$ & $26(100)$ \\
Cibogo & $9(56,3)$ & $7(43,7)$ & $16(100)$ \\
\hline total & $23(54,8)$ & $19(45,2)$ & $42(100)$ \\
\hline
\end{tabular}


Hasil pengukuran $\mathrm{pH}$ saliva sebelum aplikasi topikal fluor CPP-ACP pada anak SD Sukasari yang terendah adalah sebesar 6,91 (sampel no 1 dan 4) dan tertinggi sebesar 6,98 (sampel no 22). Hasil pengukuran $\mathrm{pH}$ saliva setelah aplikasi topikal fluor CPP-ACP satu minggu sekali selama satu bulan yang terendah adalah sebesar 7,03 (sampel no 14) dan tertinggi sebesar 7,13 (sampel no 18). Hasil memperlihatkan adanya penurunan tingkat keasaman saliva sebelum dan sesudah pemberian CPP-ACP seminggu sekali selama satu bulan di SD Sukasari. Rata rata tingkat keasaman saliva sebelum pemberian CPP-ACP sebesar 6,94 dan sesudah aplikasi CPP-ACP sebesar 7,08. Hasil analisa statistik dengan menggunakan uji $\mathrm{T}$ memperlihatkan hasil yang sangat signifikan $p<0,05$ (Diagram 1). Terdapat perbedaan selisih sebesar $-0,14$ yang artinya terdapat kenaikan tingkat keasaman $\mathrm{pH}$ saliva pada anak SD Sukasari sebelum dan sesudah aplikasi topikal fluor CPP-ACP (Tabel 2).



Diagram 1. Distribusi tingkat keasaman saliva SD Sukasari sebelum dan sesudah aplikasi CPP-ACP

Tabel 2. Perbedaan pH saliva SD Sukasari sebelum dan sesudah aplikasi CPP-ACP

\begin{tabular}{ccccc}
\hline $\begin{array}{c}\text { CPP-ACP } \\
\text { (SD Sukasari) }\end{array}$ & $\mathrm{N}$ & Selisih & $t$ & $\rho$ \\
\hline Sebelum aplikasi & 26 & $-0,14$ & $-26,09$ & $0,000^{*}$ \\
Setelah aplikasi & 26 & & & \\
\hline
\end{tabular}

Hasil pengukuran $\mathrm{pH}$ saliva sebelum aplikasi topikal fluor CPP-ACP pada anak SD Cibogo yang terendah adalah sebesar 6,87 (sampel no 6) dan tertinggi sebesar 7,12 (sampel no 10). Hasil pengukuran $\mathrm{pH}$ saliva setelah aplikasi topikal fluor CPP-ACP satu minggu sekali selama satu bulan yang terendah adalah sebesar 6,97 (sampel no 2) dan tertinggi sebesar 7,1 (sampel no 1). Hasil memperlihatkan adanya penurunan tingkat keasaman saliva sebelum dan sesudah pemberian CPP-ACP seminggu sekali selama satu bulan di SD Cibogo. Rata rata tingkat keasaman saliva sebelum 
pemberian CPP-ACP sebesar 6,92 dan sesudah

aplikasi CPP-ACP sebesar 7,03 ( Diagram 2).

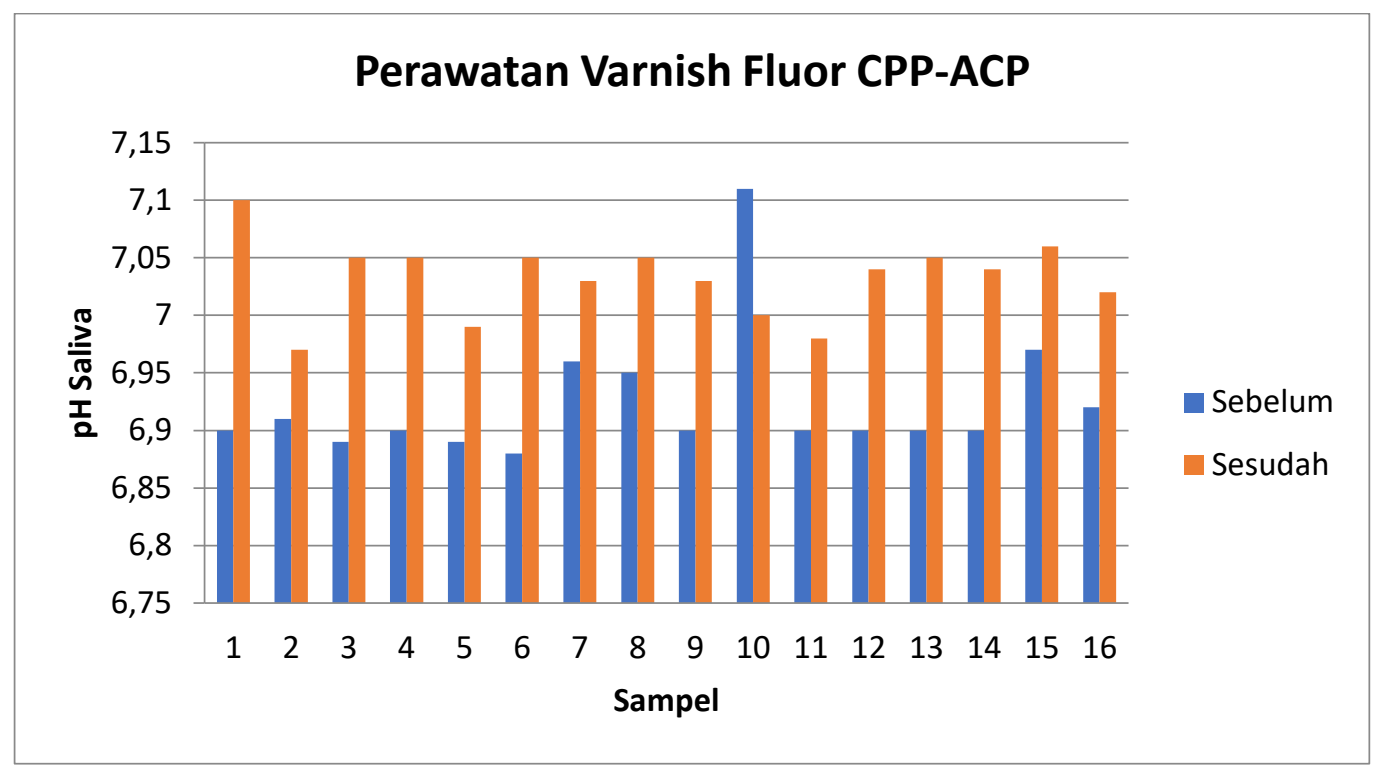

Diagram 2. Distribusi tingkat keasaman saliva SD Cibogo sebelum dan sesudah aplikasi CPP-ACP

Hasil analisa statistik dengan menggunakan uji T memperlihatkan hasil yang sangat signifikan $p<0,05$. Hasil yang serupa dengan SD Cibogo terdapat selisih sebesar $-0,10$ yang artinya terdapat kenaikan tingkat keasaman $\mathrm{pH}$ saliva pada anak SD Cibogo sebelum dan sesudah aplikasi topikal fluor CPP-ACP (Tabel 3).

Tabel 3. Perbedaan pH saliva SD Cibogo sebelum dan sesudah aplikasi CPP-ACP

\begin{tabular}{ccccc}
\hline $\begin{array}{c}\text { CPP-ACP } \\
\text { (SD Cibogo) }\end{array}$ & $N$ & Selisih & $t$ & $\rho$ \\
\hline $\begin{array}{c}\text { Sebelum aplikasi } \\
\text { Setelah aplikasi }\end{array}$ & 16 & $-0,10$ & $-5,75$ & $0,000^{*}$ \\
\hline signifikan $\rho<0,05$ & & &
\end{tabular}

Hasil penelitian untuk semua sampel penelitian yang terdiri dari anak usia 8-9 tahun SD Sukasari dan SD Cibogo memperlihatkan hamper keseluruhan anak memiliki perubahan tingkat keasaman saliva, kecuali sampel no 36 yang tidak mengalami kenaikan tingkat keasaman saliva setelah diberikan aplikasi varnish fluor CPP-ACP selama satu bulan ( Diagram 3) 


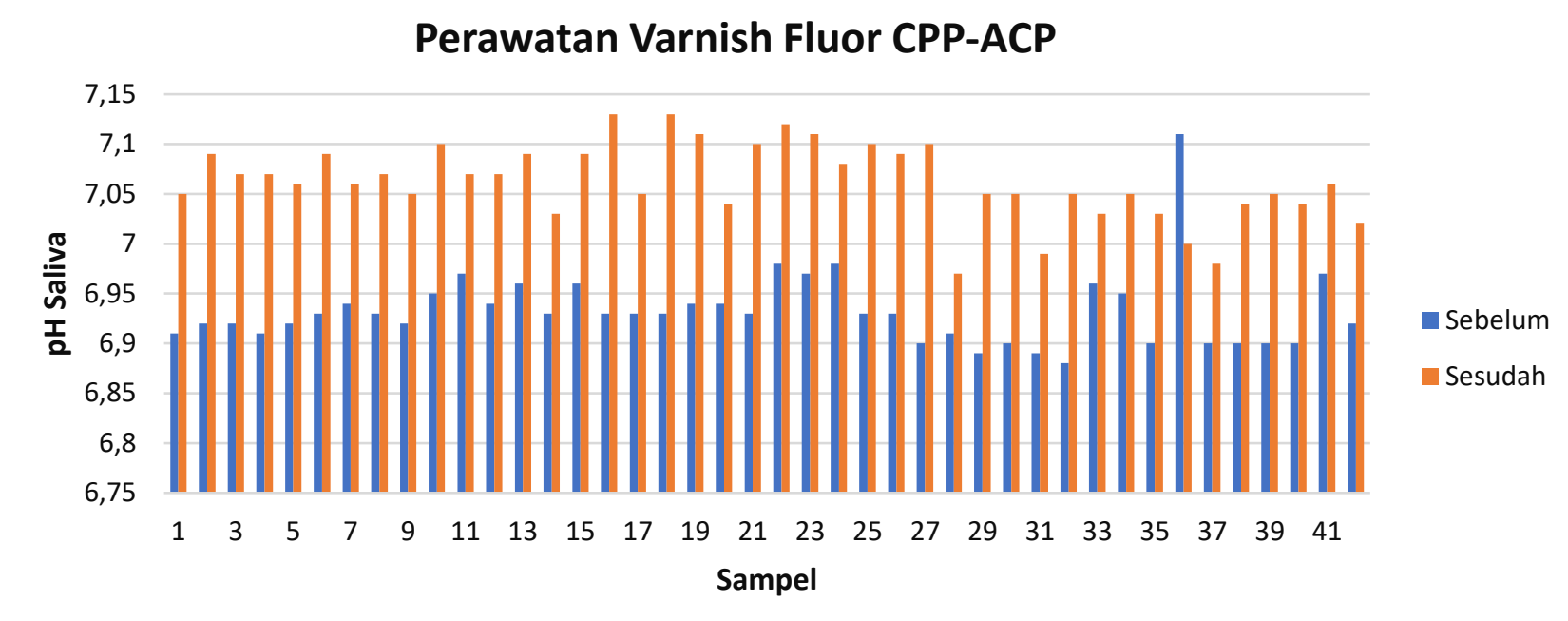

Diagram 3. Distribusi tingkat keasaman saliva SD Sukasari dan SD Cibogo sebelum dan sesudah aplikasi CPP-ACP

Hasil analisa statistik dengan menggunakan uji $\mathrm{T}$ memperlihatkan hasil yang sangat signifikan $p<0,05$. Hasil penelitian dari 2 sekolah dasar yang diteliti dihasilkan selisih $-0,13$ yang artinya terdapat pula kenaikan tingkat keasaman $\mathrm{pH}$ saliva pada anak SD Sukasari dan SD Cibogo sebelum dan sesudah aplikasi topikal fluor CPP-ACP. (Tabel 4).

Tabel 4. Perbedaan pH saliva SD Sukasari dan Cibogo sebelum dan sesudah aplikasi CPP-ACP

\begin{tabular}{ccccc}
\hline $\begin{array}{c}\text { CPP-ACP } \\
\begin{array}{c}\text { (SD Sukasari dan } \\
\text { SD Cibogo) }\end{array}\end{array}$ & $N$ & Selisih & $t$ & $\rho$ \\
\hline Sebelum aplikasi & 42 & & & \\
Setelah aplikasi & 42 & $-0,13$ & $-15,80$ & $0,000^{*}$ \\
\hline
\end{tabular}

\section{DISKUSI}

Penelitian ini menggunakan varnish CPPACP (MI varnish dari GC corporation Japan) yang diplikasikan selama satu bulan sebanyak 4 kali (satu minggu sekali). Nidhi mengemukakan bahwa mekanisme antikariogenitas pada CPP-ACP yaitu secara substantial melokalisasi ion kalsium dan fosfat pada plak, dimana menyediakan reservoir bagi ion kalsium fosfat larut pada permukaan gigi. Di bawah kondisi asam CPP berikatan dengan ACP yang hancur dan disosiasi untuk melepaskan ion kalsium dan fosfat. Mekanisme tersebut ideal untuk mencegah demineralisasi email karena adanya hubungan terbalik antara kadar kalsium pada saliva dan plak dan kadar fosfat. ${ }^{10}$
Berdasarkan hasil penelitian terdapat peningkatan rata-rata $\mathrm{pH}$ saliva sebelum dan sesudah pemberian varnish CPP-ACP (Tabel 2, 3, dan 4). Hasil pengujian statistik pengukuran $\mathrm{pH}$ saliva dengan aplikasi CPP-ACP terdapat perbedaan antara nilai $\mathrm{pH}$ saliva sebelum dan sesudah aplikasi dengan CPP-ACP. Dengan demikian, pemberian CPP-ACP pada permukaan gigi anak usia 8-9 tahun yang diberikan setiap minggu selama 1 bulan memiliki efek terhadap peningkatan $\mathrm{pH}$ saliva.

Meskipun saliva memiliki potensi remineralisasi, remineralisasi yang dihasilkan oleh saliva minimal dan terjadi pada lapisan permukaan lesi email saja. Untuk melakukan deposisi mineral 
dalam lesi email, pertama ion kalsium dan fosfat harus menembus lapisan permukaan email, hal ini menjelaskan bahwa cairan CPP sangat efisien dalam remineralisasi karena mampu mengambil asam yang dihasilkan selama terjadinya lesi email. Penelitian ini sejalan dengan penelitian yang telah dilakukan Kargul dkk dengan pemberian CPP-ACP selama 1 bulan menemukan jumlah lesi karies yang mengalami penurunan sebesar $77 \% .{ }^{11}$

Topikal fluor dalam bentuk seperti varnish tersebut memiliki kelebihan dan keunggulan tersendiri seperti varnish fluor yang merupakan metode standar emas terkini untuk melindungi gigi melawan perkembangan white spot lesion dan untuk mencegah demineralisaasi. Hal tersebut sejalan dengan penelitian Llena dkk. yang menyebutkan bahwa perbandingan efektifitas aplikasi CPP-ACP fluor dan CPP-ACP secara longitudinal mencatat bahwa setiap perawatan efektif sampai batas waktu tertentu dan tidak terdapat perbedaan efek di antara keduanya. ${ }^{12}$

\section{KESIMPULAN}

Terdapat perbedan tingkat keasaman saliva pada anak usia 8-9 tahun sebelum dan sesudah pemberian aplikasi topikal fluor CPP-ACP. Hasil menunjukkan adanya peningkatan $\mathrm{pH}$ saliva setelah pemberian CPP-ACP selama 1 minggu sekali dalam kurun waktu 1 bulan. Hal ini dapat disimpulkan bahwa CPP-ACP dapat meningkatkan ketahanan gigi terhadap proses demineralisasi dengan cara peningkatan $\mathrm{pH}$ dalam saliva.

\section{UCAPAN TERIMAKASIH}

Fakultas Kedokteran Gigi Universitas Kristen Maranatha yang telah mendukung penuh penulis untuk melakukan penelitian ini.

\section{DAFTAR PUSTAKA}

1. Stookey GK, Chin JR and Kowolik JE. Dental Caries in the Child and Adolescent. Dentistry for the Child and Adolescent.
10 $0^{\text {th }}$.St. Louis: Mosby Publications: 2015.p.177-204

2. Pinkham JR, Casamassimo PS, Fields HW Pediatric Dentistry Infancythrough adolescence. $4^{\text {th }}$ ed. St. Louise, Missouri: Elsevier Inc; 2005.p. 199-204.

3. Culp DJ, Robinson B, Parkkila S, Pan PW, Cash MN, Truong HN ,et al. Oral Colonization by streptococcus mutans and caries development is reduce upon detection of carbonic anhydrase $\mathrm{VI}$ expression in saliva. Biochim Biophys. 2011:1567-76.

4. Yang $F$, Zeng X, Ning K, Liu KL, Lo CC, Wang $W$, et al. Saliva mikrobiomes distinguish caries - active from healthy human populations. ISME J. 2012; 6:1-10.

5. Kardos $T$ dan Kieser J. Clinical Oral Biology. $2^{\text {nd }}$ ed. New Zealand. 2000; 11: $93-$ 101.

6. Ahmadi Motamayed F, Goodarzi MT, Hendi SS, Kasraei S, Moghimbeigi A. Total antioxidant capacity of saliva and dental caries. Med Oral Patol Oral Cir Bucal. 2013; 18: 553-6.

7. Denny PC. A saliva-based prognostic test for dental caries susceptibility. J Dent Hyg. 2009;83:175-6.

8. Fudali-Walczak m, Raba G, Obloza B. Saliva $\mathrm{pH}$ testing in predicting dental caries in children age 7-10 years. Prz Med Uniw Rzesz Inst Lekow. 2015;13(2):90-94.

9. Fajriani dan Aini DH. Efek Aplikasi Topikal Casein Phospopeptide-Amorfphous Calcium Phospat dan Sodium Fluoride pada Streptococcus mutans saliva pada anak. Departemen Pediatric Dentistry. Faculty of Dentistry, Universitas Hasanuddin.

10. Nidhi C dan Anuj C. Enhanced Remineralisation of Tooth Enamel Using Casein Phospopeptide-Amorphous Calcium Phosphate Complex : A Review. Int J Clin Pre Dent. 2018;14(1):1-10.

11. Kargul B, Durmus B dan Bekiroglu N. Effect of CPP-ACP on Remineralisation of Early Caries Lesions in Primary Teeth. OHDM. 2017; 16 (3).

12. Llena $\mathrm{C}$, Leyda $\mathrm{AM}$ dan Forner L. CPPACP and CPP-ACFP Versus Fluoride Varnish in Remineralisation on Early Caries Lesions. A Prospective Study. European Journal of Paediatric Dentistry. 2015;16(3) 